\title{
Effects of Pseudoephedrine Administration in Early Gestation on Female Mouse Heart
}

\author{
Annisa Rahmah Furqaani, ${ }^{1}$ Listya Hanum Siswanti, ${ }^{1,2}$ Ajeng Kartika Sari1,2 \\ ${ }^{1}$ Department of Histology and Biomedical Sciences, Faculty of Medicine, Universitas Islam Bandung, \\ Bandung, Indonesia, ${ }^{2}$ Graduate School of Biomedical Sciences Master Program, \\ Faculty of Medicine, Universitas Padjadjaran, Bandung, Indonesia
}

\begin{abstract}
The pseudoephedrine in pregnant women associated with an increased risk of hypertension and increased heart rate. These conditions force the heart to work harder and cause changes in heart structure, such as left ventricular hypertrophy due to an increase in the number and size of muscle cells. This study aims to determine pseudoephedrine administration in early pregnancy on mice hearts histological features. This study was pure in vivo with a completely randomized design conducted at Medical Biology Laboratory, Faculty of Medicine, Universitas Islam Bandung, from January to August 2017. Subjects were 18 pregnant adult female mice randomly divided into four groups. One control group and three test groups were given oral pseudoephedrine every day at $0.312 \mathrm{mg} / 24$ hours (P1); 0.624 $\mathrm{mg} / 24$ hours (P2); and $1.248 \mathrm{mg} / 24$ hours $\left(\mathrm{P}_{3}\right)$ for seven days starting from the age of pregnancy on day 1 . On the $18^{\text {th }}$ day of gestational age, mice sacrificed, then the heart organ was processed into microscopic preparations and stained by Harris' hematoxylin-eosin (HE) staining. Microscopic observations made using a microscope equipped with an optilab viewer with raster image 3 . The results showed that the $P_{3}$ group had a thicker left ventricular wall and significantly more heart muscle nuclei per $\mathrm{mm}^{3}$ than the control group $(\mathrm{p}<0.05)$. The results show that the administration of high doses of pseudoephedrine in early pregnancy can affect the structure of the heart.
\end{abstract}

Key words: Gestation, heart histology, pseudoephedrine

\section{Pengaruh Pemberian Pseudoefedrin pada Masa Awal Kebuntingan terhadap Gambaran Histologi Jantung Mencit Betina}

\begin{abstract}
Abstrak
Aktivitas vasokontriksi pseudoefedrin pada ibu hamil diduga kuat berkaitan dengan peningkatan risiko hipertensi dan denyut jantung. Kondisi tersebut memaksa jantung bekerja lebih berat dan dapat menyebabkan perubahan struktur jantung seperti hipertrofi ventrikel kiri akibat peningkatan jumlah dan ukuran sel-sel otot. Tujuan penelitian ini mengetahui pengaruh pemberian pseudoefedrin pada masa awal kebuntingan terhadap gambaran histologi jantung mencit betina. Penelitian ini merupakan eksperimental laboratorium murni in vivo menggunakan rancangan acak lengkap yang dilaksanakan di Laboratorium Biologi Medik, Fakultas Kedokteran, Universitas Islam Bandung dari bulan Januari hingga Agustus 2017. Subjek penelitian adalah 18 mencit betina dewasa bunting yang dibagi secara acak menjadi empat kelompok. Satu kelompok kontrol dan tiga kelompok uji yang diberi pseudoefedrin oral setiap hari dengan dosis 0,312 mg/24 jam (P1); 0,624 mg/24 jam (P2); dan 1,248 mg/24 jam ( $\left.\mathrm{P}_{3}\right)$ selama 7 hari dimulai dari umur kebuntingan hari ke-1. Pada hari ke-18 umur kebuntingan, mencit dikorbankan kemudian organ jantung diproses menjadi sediaan mikroskopis dan dilakukan pewarnaan Harris' hematoxylin-eosin (HE). Pengamatan sediaan mikroskopik dilakukan dengan menggunakan mikroskop yang dilengkapi dengan optilab viewer dengan image raster 3 . Hasil penelitian menunjukkan kelompok $\mathrm{P}_{3}$ memiliki dinding ventrikel kiri yang lebih tebal dan jumlah nuklei otot jantung yang lebih banyak per $\mathrm{mm}^{3}$ secara signifikan dibanding dengan kelompok kontrol $(\mathrm{p}<0,05)$. Hasil menunjukkan bahwa pemberian pseudoefedrin dosis tinggi pada masa awal kehamilan dapat memengaruhi struktur jantung.
\end{abstract}

Kata kunci: Histologi jantung, kehamilan, pseudoefedrin

Received: 2 December 2019; Revised: 26 December 2019; Accepted: 28 December 2019; Published: 31 December 2019

Correspondence: Annisa Rahmah Furqaani. Department of Histology and Biomedical Sciences, Faculty of Medicine, Universitas Islam Bandung. Jln. Tamansari No. 22, Bandung 40116, West Java, Indonesia. E-mail: annisarahmahf@gmail.com 


\section{Introduction}

Drug use in pregnant women has increased over the past 3-4 years in the United States and other countries. In the United States, drug use by pregnant women increased by $68 \%$ from 2.6 in 1976-1978 to 4.2 in 2006-2008. At present, almost half of pregnant women have used more than four types of drugs simultaneously. ${ }^{1}$ In several developing countries, antenatal prescription drug is common. The majority of pregnant women who use one or more drugs recognized as having potential risks in pregnancy. ${ }^{2}$ Lupattelli et al. ${ }^{3}$ showed that more than $80 \%$ of pregnant women in Europe, Australia, and America use at least one drug during the pregnancy. During 2006-2008, more than $90 \%$ of women reported using one over-the-counter (OTC) drug during pregnancy. ${ }^{4}$ The above results show that drug use in pregnant women is common.

One of the most common infection-related diseases in pregnant women is the common cold. ${ }^{5,6}$ Various free drug brands that have limited functions to relieve the symptoms are widely available. Therefore pregnant women can easily access these drugs to relieve the symptoms. ${ }^{3,7}$ Drug consumption not recommended for pregnant women, especially in the first 12 weeks which is an essential period of vital organ development.4,6,8

Pseudoephedrine is the most widely used decongestant during pregnancy because it can be obtained without a prescription and is widely considered a safe drug by pregnant women and healthcare providers. ${ }^{9,10}$ This decongestant is an $\alpha$ - and $\beta$-adrenoceptor agonist, activation of $\alpha$-adrenoceptors in the nasal mucosa causes vasoconstriction and reduces nasal obstruction. ${ }^{11}$ Pseudoephedrine also plays a role in increasing $\mathrm{NE}$ release into the synaptic cleft and causing adrenoceptor activation in postsynaptic neurons. ${ }^{12}$

Vasoconstriction caused by pseudoephedrine suspected to associate with an increased risk of congenital defect due to vascular disorders in the first-trimester pregnancy. The activity also increases the risk of hypertension. ${ }^{13}$ Physiologically, in pregnant women, there is an increase in heart work as a form of compensation to supply adequate nutrition and oxygen to the fetus. ${ }^{13,14}$ Thus, pseudoephedrine use in pregnancy will cause the heart to work harder. The use of pseudoephedrine oral or nasal more than five days can cause a cardiovascular effect. ${ }^{15}$ This condition can cause changes in heart structure, including left ventricular hypertrophy due to an increase in the number and size of muscle cells, thickening and enlargement of the left atrium, narrowing of the heart lumen, and enlargement of the heart valves. ${ }^{16}$ This study conducted to describe the effect of pseudoephedrine administration in early pregnancy on the histological feature of the mice heart.

\section{Methods}

This study was in vivo laboratory experiments with a completely randomized design conducted at Medical Biology Laboratory, Faculty of Medicine, Universitas Islam Bandung, from January to August 2017. Twenty adult gestational mice (Mus musculus) divided into four groups: one control (C) and three treated groups ( $\mathrm{P}_{1}, \mathrm{P}_{2}$, $\mathrm{P}_{3}$ ), but two mice in $\mathrm{P}_{2}$ and $\mathrm{P}_{3}$ groups died over the study. Based on the monthly index of medical specialties (MIMS) 2016, the maximum dose of pseudoephedrine used in adult humans is 240 $\mathrm{mg} / 24$ hours for seven days. Because the subjects in this study were mice, the dose equalization with a conversion factor of 0.0026 conducted to obtain a dose of $0.624 \mathrm{mg} / 24$ hours (n). The effect of various pseudoephedrine doses on the general teratological feature of mice fetuses determined with two other doses. The doses were 0.312 $\mathrm{mg} / 24$ hours (1/2n) and $1.248 \mathrm{mg} / 24$ hours (2n) and administered for seven days.

Mice adapted for two weeks before treatment. Unhealthy mice during and after this period not included in the study. During treatment, mice placed in a cage made of plastic tubs $28 \times 34 \times 14$ $\mathrm{cm}$ covered with small wire mesh and given husk base to absorb urine and feces. Each tub filled with a maximum of five animals. Mice fed ad libitum, and tap water also provided ad libitum. Cage cleaning and husk replacement at least once a week.

Female mice mated naturally with male mice by uniting the two in one cage in a ratio of 5 females: 1 male. Determination of gestational age by observing the absence/presence of vaginal plugs in the next morning. If vaginal plugs found, it counted as day-o of gestation.

This study was part of a research project that also observes the teratological features of mice's offspring. The standard procedure for teratological observation was that the dissection performed on the $18^{\text {th }}$ day of gestation to minimize bias related to gestational age. ${ }^{17}$ On the $18^{\text {th }}$ day of gestation, mice sacrificed by dislocation and dissected. The heart weighed, then immersed 
in the $10 \%$ formalin solution, processed into microscopic preparations, and stained with the Harris' hematoxylin-eosin (HE) staining. The preparation was observed using a microscope equipped with an optilab viewer 2.2 and image raster three software for analysis. Morphology of the left ventricle and number of cardiocytes were analyzed. The cardiocytes' percentage calculation carried out in each field of view. Mean values from all fields calculated from all preparations of each group. Afterward, it followed by calculating the mean of each group.

Data obtained from this study were heart weight, left ventricular wall thickness, and the number of cardiocytes nuclei. The data analyzed using one-way ANOVA with post-hoc Bonferroni.

\section{Results}

The macroscopic and microscopic observation from this study presented in Table.

Based on the data in Table, it appears that cardiac wet weight tends to increase in the treatment group ( $\mathrm{P}_{1}, \mathrm{P}_{2}$, and $\left.\mathrm{P}_{3}\right)$ who received pseudoephedrine doses of $0.312 \mathrm{mg} / 24$ hours, $0.624 \mathrm{mg} / 24$ hours, and $1.248 \mathrm{mg} / 24$ hours, but the increase not statistically significant $(p>0.05)$. The thickness of the left ventricle also increased, but only the $\mathrm{P} 3$ group showed a significant difference compared to the control group. The number of nuclei (cardiomyocytes) in the $\mathrm{P}_{3}$ group were significantly increased compared to the control group $(\mathrm{p}<0.05)$.

\section{Discussion}

This study shows that the number of cardiomyocyte nuclei increases in line with the dose of pseudoephedrine. The number of nuclei represents the number of cardiomyocytes. Therefore, the number of cardiomyocyte in treatment groups tend to increase along with the given dose. Based on these data, it concluded that the addition of left ventricular wall thickness in this study caused by hyperplasia or an increase in the number cardiomyocyte in that ventricular section. Farrell et al. ${ }^{18}$ showed that in the hypertrophic cardiomyopathy mouse model, hyperplasia contributed to increasing the size of the heart. Hyperplasia is a process that stimulated by cytokines produced by cardiomyocytes and is a factor that plays a role in increasing left ventricular mass in rats with chronic overload volume. ${ }^{19}$ During pregnancy, there is an increase in blood volume, hormonal changes, and a gradual increase in cardiac output until it reaches a peak in late pregnancy. ${ }^{20}$ Simultaneously, there is an increase in heart rate and stroke volume or a decrease in vascular resistance. ${ }^{21}$ As a result of hematological and hormonal changes in pregnancy, the heart forced to work harder so its structure must undergo adaptation, including mild hypertrophy in the left ventricle thus homeostasis to the fetus can be maintained. ${ }^{20,22}$

In this study, increasing in cardiomyocytes number and ventricular wall thickness has not contributed significantly to heart weight. Nevertheless, it tended to be more substantial in the treatment group. The high dose pseudoephedrine $(1.248 \mathrm{mg} / 24$ hours $)$ in early pregnancy can affect the structure of the heart. Without drug interference, pregnancy itself is one of the conditions that cause remodeling of the heart structure toward hypertrophy. ${ }^{23}$ In late pregnancy model, fibroblast growth factor 21 (FGF21) plays the leading role in cardiac hypertrophy. ${ }^{24}$ FGF21 is cardiomyocyte produced by cardiomyocyte and works as autocrine,

Table Macroscopic and Microscopic Observation from Heart Preparation

\begin{tabular}{lccccc}
\hline Parameters & $\begin{array}{c}\mathbf{C} \\
(\mathbf{n = 5})\end{array}$ & $\begin{array}{c}\mathbf{P 1} \\
(\mathbf{n = 5})\end{array}$ & $\begin{array}{c}\mathbf{P 2} \\
(\mathbf{n = 4})\end{array}$ & $\begin{array}{c}\text { P3 } \\
(\mathbf{n = 4})\end{array}$ & $\begin{array}{c}\mathbf{p} \\
\text { Value }\end{array}$ \\
\hline $\begin{array}{l}\text { Heart weight }(\mathrm{g}) \\
\begin{array}{c}\text { Left ventricle } \\
\text { thickness }(\mu \mathrm{m})\end{array}\end{array}$ & $\mathbf{0 . 1 9 ( 0 . 0 1 )}$ & $0.19(0.04)$ & $0.24(0.06)$ & $0.21(0.01)$ & 0.401 \\
$\begin{array}{c}\text { Number of nuclei } \\
\left(10^{-6} / \mathrm{mm}^{3}\right)\end{array}$ & $35.56(3.73)$ & $49.70(7.43)$ & $61.98(15.85)$ & $80.29(6.19)^{*}$ & 0.000 \\
\hline
\end{tabular}

Note: data presented in mean (standard deviation); Statistical analysis for each parameter using the one-way ANOVA test with Bonferroni's advanced test at a 95\%CI $(\alpha=0.05) ; n=$ number of samples; $\mathrm{C}=$ control group; P1=treatment group received pseudoephedrine dose $0.312 \mathrm{mg} / 24$ hours; $\mathrm{P}_{2}=$ treatment group received pseudoephedrine dose of $0.624 \mathrm{mg} / 24$ hours; $\mathrm{P}_{3}=$ treatment group received pseudoephedrine dose and 1,248 mg/24 hours; *significantly different with C 
paracrine, or endocrine. FGF21 in response to hypertrophy or other stress stimuli and is known for preventing cardiac hypertrophy, heart inflammation, and inhibiting oxidative stress activity. ${ }^{25}$ FGF21 levels are relatively elevated during pregnancy and mediated by transcription factor peroxisome proliferator-activated receptor a (PPARa). The intracellular mechanism of action of FGF21 involves PPARa and Sirt1 which influence the regulation of transcription of FGF21 genes when exposed to exogenous stimuli. ${ }^{24}$

Cardiac hypertrophy is a physiological adaptation during pregnancy so that the survival of the fetus ensured..$^{20}$ Cardiovascular system adjustment during pregnancy can turn out to be pathological if accompanied by certain conditions, such as the consumption of certain drugs, ${ }^{8,10}$ including pseudoephedrine. Nevertheless, based on the United States Food and Drug Administration (FDA) category, pseudoephedrine is in category C. It means that in animal and human studies, it shows side effects in the fetus (teratogenic or embryocidal). However, controlled studies in both are still not yet available or adequate. ${ }^{8}$ This drug should only be given to pregnant women only if the potential benefits are more significant than the risk to the fetus. Unfortunately, lacking information received by pregnant women regarding the safety drugs during pregnancy and free circulation in the market makes it easily accessible to pregnant women. ${ }^{26}$ More than $90 \%$ of pregnant women exposed to the OTC drug. ${ }^{7}$

Pseudoephedrine is a vasoconstrictor agonist $\alpha$ - and $\beta$-adrenoceptor. ${ }^{11}$ Pseudoephedrine can bind the norepinephrine (NE) transporter and SLC6A2. Therefore it plays a role in releasing neurotransmitter NE. ${ }^{12} \mathrm{NE}$ is a sympathomimetic agent that causes an increase in heart rate, blood pressure, and cardiac output. ${ }^{11}$ In pregnancy, pseudoephedrine potentially cause hypertension and increased work of the cardiovascular system. Hypertension can become a significant cause of left ventricle hypertrophy mediated by neuropeptide $\mathrm{Y}$ (NPY). It has vasoconstrictive and pro-angiogenic properties. It induced remodeling in response to hemodynamic overload. Long term hypertension can stimulate cardiomyocyte proliferation and decreased cardiac ventricular function. ${ }^{27}$

The cellular and molecular mechanism of pseudoephedrine in causing hypertrophy is not known certainly. Does it contribute to causing cardiac hypertrophy through enhancing NE release or it has the potential to influence the cardiomyocyte's proliferation pathway? It is necessary to further investigate the effect of pseudoephedrine utilization on factors related to cardiomyocytes hypertrophy and hyperplasia, including FGF21 and Sirt1 gene expression.

\section{Conclusion}

Administration of high doses of pseudoephedrine in early pregnancy can affect the structure of the mice's heart.

\section{Conflict of Interest}

There was no conflict of interest.

\section{Acknowledgment}

This study funded by Institute for Research and Community Service (Lembaga Penelitian dan Pengabdian kepada Masyarakat/LPPM) Universitas Islam Bandung.

\section{References}

1. Ayad M, Costantine MM. Epidemiology of medications use in pregnancy. Semin Perinatol. 2015;39(7):508-11.

2. Daw JR, Hanley GE, Greyson DL, Morgan SG. Prescription drug use during pregnancy in developed countries: a systematic review. Pharmacoepidemiol Drug Saf. 2011;20(9):895-902.

3. Lupattelli A, Spigset O, Twigg MJ, Zagorodnikova $\mathrm{K}$, Mårdby $\mathrm{AC}$, Moretti $\mathrm{ME}$, et al. Medication use in pregnancy: a crosssectional, multinational web-based study. BMJ Open. 2014;4(2):e004365.

4. Thorpe PG, Gilboa SM, Hernandez-Diaz S, Lind J, Cragan JD, Briggs G, et al. Medications in the first trimester of pregnancy: most common exposures and critical gaps in understanding fetal risk. Pharmacoepidemiol Drug Saf. 2013;22(9):1013-8.

5. Kourtis AP, Read JS, Jamieson DJ. Pregnancy and infection. N Engl J Med. 2014;370(23):2211-8.

6. Mor G, Cardenas I. The immune system in pregnancy: a unique complexity. Am $\mathrm{J}$ Reprod Immunol. 2010;63(6):425-33.

7. Sachdeva P, Patel BG, Patel BK. Drug use in pregnancy; a point to ponder! Indian $\mathrm{J}$ Pharm Sci. 2009;71(1):1-7. 
8. Mosley AT, Witte AP. Drugs in pregnancy: do the benefits outweigh the risks? US Pharmacist. 2013;38(9):43-6.

9. Werler MM. Teratogen update: Pseudoephedrine. Birth Defects Res A Clin Mol Teratol. 2006;76(6):445-52.

10. Yau WP, Mitchell AA, Lin KJ, Werler MM, Hernández-Díaz S. Use of decongestants during pregnancy and the risk of birth defects. Am J Epidemiol. 2013;178(2):198-208.

11. Solanki P, Yadav PP, Kantharia ND. Ephedrine: direct, indirect or mixed acting sympathomimetic? Int $\mathrm{J}$ Basic Clin Pharmacol. 2014;3(3):431-6.

12. Schlessinger A, Geier E, Fan H, Irwin JJ, Shoichet BK, Giacomini KM, et al. Structure-based discovery of prescription drugs that interact with the norepinephrine transporter, NET. Proc Natl Acad Sci USA. 2011;108(38):15810-5.

13. van Gelder MMHJ, van Rooij IALM, Miller RK, Zielhuis GA, de Jong-van den Berg LTW, Roeleveld N. Teratogenic mechanisms of medical drugs. Hum Reprod Update. 2010;16(4):378-94.

14. Costantine MM. Physiologic and pharmacokinetic changes in pregnancy. Front Pharmacol. 2014;5:65.

15. Laccourreye O, Werner A, Giroud JP, Couloigner V, Bonfils P, Bondon-Guitton E. Benefits, limits and danger of ephedrine and pseudoephedrine as nasal decongestants. Eur Ann Otorhinolaryngol Head Neck Dis. 2015;132(1):31-4.

16. Lazzeroni D, Rimoldi O, Camici PG. From left ventricular hypertrophy to dysfunction and failure. Circ J. 2016;80(3):555-64.

17. Peraturan Kepala Badan Pengawas Obat dan Makanan Republik Indonesia Nomor 7 Tahun 2014 tentang Pedoman Uji Toksisitas Nonklinik secara In Vivo.

18. Farrell ET, Grimes AC, de Lange WJ, Armstrong AE, Ralphe JC. Increased postnatal cardiac hyperplasia precedes cardiomyocyte hypertrophy in a model of hypertrophic cardiomyopathy. Front Physiol. 2017;8:414.

19. Du Y, Plante E, Janicki JS, Brower GL. Temporal evaluation of cardiac myocyte hypertrophy and hyperplasia in male rats secondary to chronic volume overload. Am J Pathol. 2010;177(3):1155-63.

20. Xiao J, Li J, Xu T, Lv D, Shen B, Song Y, et al. Pregnancy-induced physiological hypertrophy protects against cardiac ischemia-reperfusion injury. Int J Clin Exp Pathol. 2014;7(1):229-35.

21. Yanamandra N, Chandraharan E. Anatomical and physiological changes in pregnancy and their implications in clinical practice. In: Chandraharan E, Arulkumaran SS, editors. Obstetric and intrapartum emergencies: a practical guide to management. Cambridge: Cambridge University Press; 2013. p. 1-8.

22. Soma-Pillay P, Nelson-Piercy C, Tolppanen $\mathrm{H}$, Mebazaa A. Physiological changes in pregnancy. Cardiovasc J Afr. 2016;27(2):8994.

23. Maillet M, van Berlo JH, Molkentin JD. Molecular basis of physiological heart growth: fundamental concepts and new players. Nat Rev Mol Cell Biol. 2013;14(1):38-48.

24. Redondo-Angulo I, Mas-Stachurska A, Sitges M, Tinahones FJ, Giralt M, Villarroya $\mathrm{F}$, et al. Fgf21 is required for cardiac remodeling in pregnancy. Cardiovasc Res. 2017;113(13):1574-84.

25. Planavila A, Redondo-Angulo I, Villarroya F. FGF21 and cardiac physiopathology. Front Endocrinol (Lausanne). 2015;6:133.

26. Clemow DB, Dewulf L, Koren G, Mikita JS, Nolan MR, Michaels DL, et al. Clinical data for informed medication use in pregnancy: strengths, limitations, gaps, and a need to continue moving forward. Ther Innov Regul Sci. 2014;48(2):134-44.

27. Tan CMJ, Green P, Tapoulal N, Lewandowski AJ, Leeson P, Herring N. The role of neuropeptide $\mathrm{Y}$ in cardiovascular health and disease. Front Physiol. 2018;9:1281. 